\title{
Two new records of octocorals (Anthozoa, Octocorallia) from north-west Australia
}

\author{
Monika Bryce $e^{1,3}$ and Angelo Poliseno ${ }^{2}$ \\ ${ }^{1}$ Western Australian Museum, Locked Bag 49, Welshpool DC, Perth,Western Australia 6986, Australia \\ 2 Department of Earth and Environmental Sciences, Paleontology and Geobiology Ludwig-Maximilians- \\ University Munich, Richard-Wagner Strasse 10, 80333 Munich, Germany \\ ${ }^{3}$ Queensland Museum, PO Box 3300, South Brisbane BC, Queensland 4101, Australia
}

Email: monika.bryce@museum.wa.gov.au

KEYWORDS: Stolonifera, Indian Ocean, new locality records, Western Australia; Ashmore Reef, Hibernia Reef, Coelogorgiidae, Coelogorgia palmosa, Ifalukellidae, Plumigorgia hydroides

\section{INTRODUCTION}

In 2012 and 2013 the Western Australian Museum (WAM) undertook a comprehensive biodiversity survey in the Sahul Shelf Bioregion, which encompassed the intertidal and shallow subtidal reef communities of the outer shelf atolls of Ashmore and Hibernia Reefs, and several submerged midshelf shoals. While the outer shelf has seen some octocoral sampling effort in the past, there was no information from the midshelf region (Marsh 1986, 1993; Griffith 1997; Kospartov et al. 2006, Fabricius 2008; Bryce and Sampey 2014).

The eastern section of the Sahul Shelf Bioregion between longitudes $123^{\circ} 20^{\prime}$ and $130^{\circ} 46^{\prime} \mathrm{E}$ is characterised by three platform coral reefs and a series of submerged shoals (Wilson 2013). These structures are true bioherms, built by the accumulation of marine biogenic carbonate during periods of submergence in the Pliocene. While the Kimberley coast is mainly characterised by a low energy wave regime, turbid coastal water conditions, and local tidal currents, the Oceanic Shoal Bioregion has a high wave regime, clear oceanic water conditions and is influenced by the Indonesian Throughflow and Holloway Currents (Wilson 2013).

Examination of octocoral species from these recent surveys, paired with unidentified historic material from the WAM collection has revealed the occurrence of Plumigorgia hydroides Nutting, 1910 and Coelogorgia palmosa Milne-Edwards \& Haime, 1857 in Australian waters. Our intention here is to report on the distribution of these octocorals in Australia and support our findings with molecular analyses for DNA barcoding.

\section{MATERIALS AND METHODS}

Material was collected by SCUBA (Figure 1). Specimens were photographed in situ and on deck and preserved in both $70 \%$ ethanol for taxonomic investigation and in $100 \%$ ethanol for genetic investigation. DNA extraction of preserved tissue was done using a Phenol/Chloroform method. Amplification of the octocoral-specific gene $m t M u t S$ was performed following standard PCR protocols using primers ND42599F (France and Hoover, 2002) and Mut3458R (Sánchez et al., 2003). The mtMutS sequences obtained were initially compared against sequences for congeneric species and afterwards aligned with other octocoral sequences available in GenBank. Maximum likelihood and Bayesian methods were considered for phylogenetic analysis.

Biodiversity surveys were conducted on 30 reef sites over a strip typically 200 to $300 \mathrm{~m}$ long and $2 \mathrm{~m}$ wide within a 45 minute timed swim. Relative abundances were visually estimated on a rating scale of $0-5$ : $0=$ absent; 1 = one or few colonies; 2 = uncommon; $3=$ common; 4 = abundant; and $5=$ dominant (Table 1) (Fabricius and De'ath 2001). Historical material from the WAM collection was also examined. All specimens have been registered and deposited in the WAM, Perth.

Site Description: Ashmore Reef (12 $\left.17^{\circ} \mathrm{S}, 123^{\circ} 0.2^{\prime} \mathrm{E}\right)$ is the largest and most mature platform reef on the north-western side of the Sahul Shelf, $350 \mathrm{~km}$ off the Kimberley coast (Wilson 2013). Approximately $26 \mathrm{~km}$ long and $14 \mathrm{~km}$ wide $(150 \mathrm{sq} \mathrm{km})$, it has three low vegetated supratidal cays, a large lagoon and an extensive shoal area less than $50 \mathrm{~m}$ deep. The southern and windward reef edge has an unbroken margin. It is backed by extensive sand flats and an outer reef slope characterised by strong surge channels which 


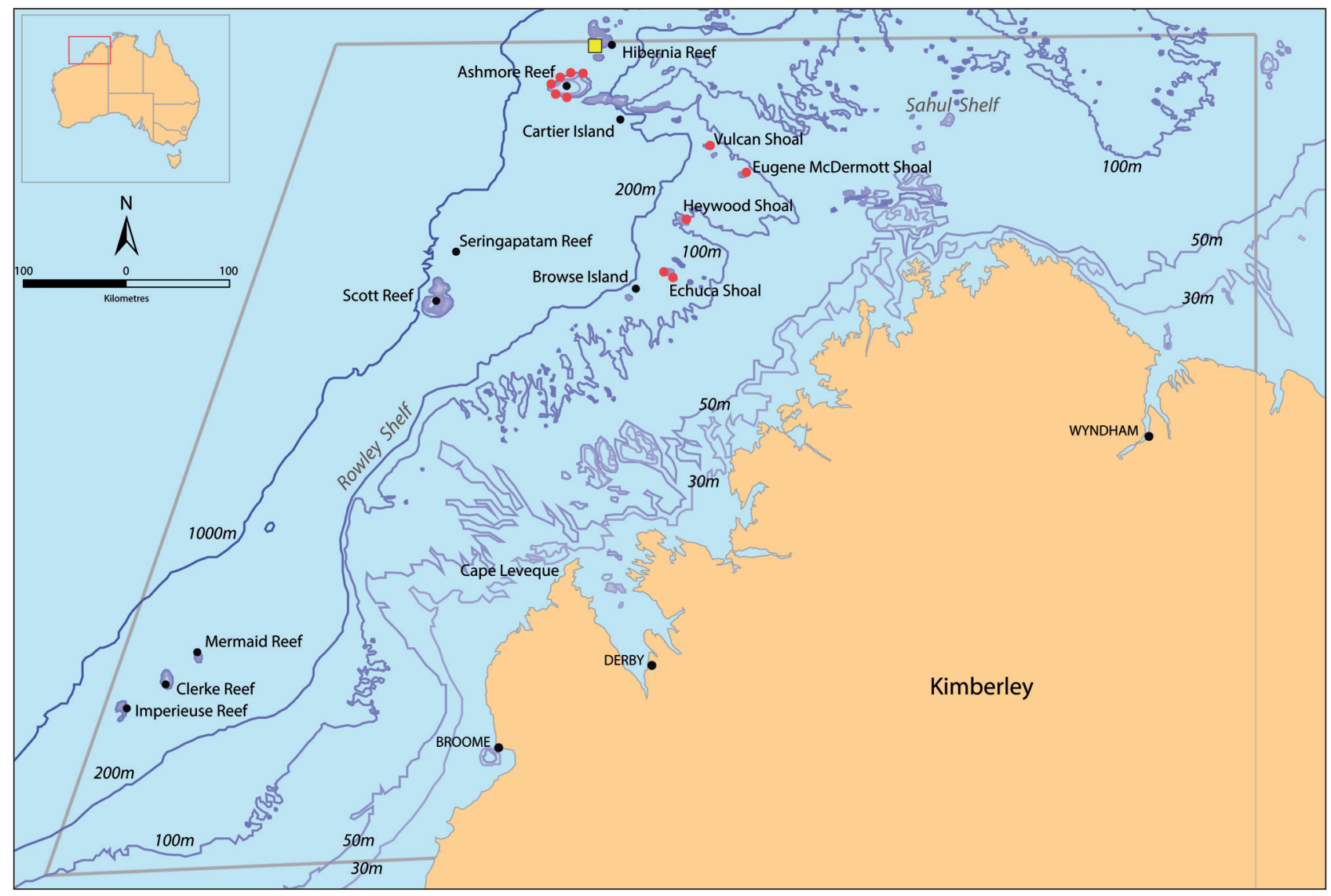

FIGURE 1 Locations of the new octocoral records. The area of study in the Kimberley is bounded by a grey line. Locations of Coelogorgia palmosa are marked as red circles and Plumigorgia hydroides as a yellow square.

develop into spur and groove formations (Wilson 2013). The leeward northern margins are broken by several passages leading into two extensive shallow lagoons and the outer reef slope is very steep. To the north-east of Ashmore reef is an extensive and complex system of submerged reefs, with only Hibernia Reef being emergent. Hibernia Reef is a coral rich, intertidal platform with a shallow lagoon. To the south-east lie the submerged shoals (Vulcan, Eugene McDermott, Heywood and Echuca Shoals) with hard rock foundation and low coral cover. Locations of the octocoral records are provided in Figure 1.

\section{SYSTEMATIC RESULTS}

\section{Family Coelogorgiiidae Bourne, 1900 Monogeneric}

\section{Genus Coelogorgia Milne-Edwards \& Haime, 1857 Monotypic}

\section{TYPE SPECIES}

Coelogorgia palmosa Milne-Edwards \& Haime, 1857 (by monotypy).

\section{DIAGNOSIS}

Colonies are aborescent and have a bushy growth form. Axial polyps are very long; lateral polyps are numerous and short. Axial region of colonies is hollow. Primary polyp wall thickened and penetrated by numerous solenia. Sclerites are tuberculated spindles. Stolon reduced to a spreading holdfast. (Williams 1992).

\section{Coelogorgia palmosa Milne-Edwards \& Haime, 1857}

(Figures 2, 3, 7; Table 1)

Coelogorgia palmosa Milne-Edwards \& Haime, 1857: 191; Wright \& Studer, 1889: 266-269, pl. 43 figs 1-8; Thomson \& Henderson 1906: 435-436; Thomson \& Dean, 1931: 215-216; Tixier-Durivault, 1966: 24-25, figs. 7-9; Verseveldt, 1971: 4-5; Williams, 1992: 266.

\section{MATERIAL EXAMINED}

WAM Z66904, three whole specimens, Station 122/K13, Ashmore Reef, NW Australia, $12.23065^{\circ} \mathrm{S}$, $122.99998^{\circ} \mathrm{E}$, SCUBA, depth $12 \mathrm{~m}$, collected $\mathrm{M}$. Bryce, 25 September 2013; WAM Z67016, four whole specimens, Station 132/K13, Ashmore Reef, NW Australia, $12.17297^{\circ} \mathrm{S}, 123.06116^{\circ} \mathrm{E}$, SCUBA, depth $14 \mathrm{~m}$, 
TABLE 1 Habitat description from stations were Plumigorgia hydroides* and Coelogorgia palmosa were reported. Stations in Marsh (1993) correspond to stations in this report in parenthesis. Relative abundances of octocoral genera: 1 = one or few colonies; 2 = uncommon; 3 = common; 4 = abundant.

\begin{tabular}{|c|c|c|c|c|}
\hline Station & Location & Depth (m) & Abundance & Habitat \\
\hline $\begin{array}{l}107 \\
108\end{array}$ & Echuca Shoal & $\begin{array}{l}22 \\
19\end{array}$ & $\begin{array}{l}1 \\
1\end{array}$ & $\begin{array}{l}\text { Wave and current swept isolated shoal - mostly bare } \\
\text { rock, coarse coralline sand and rubble with small to } \\
\text { medium rocky outcrops. Undercut sections of the } \\
\text { outcrops supported a rich variety of benthic invertebrate } \\
\text { life. }\end{array}$ \\
\hline $\begin{array}{l}109 \\
148\end{array}$ & Heywood Shoal & $\begin{array}{l}23 \\
23\end{array}$ & $\begin{array}{l}1 \\
1\end{array}$ & $\begin{array}{l}\text { Wave and current swept isolated shoal - mostly bare } \\
\text { rock, coral boulders, tunable rocks, and rocky outcrops. } \\
\text { Shallow surge channels with coarse coralline sand. Low } \\
\text { profile ledges provide a concentration point for marine } \\
\text { invertebrate life }\end{array}$ \\
\hline
\end{tabular}

Lagoon - back reef at edge of channel dotted with large flat topped coral outcrops and ridges, fine sediment and coral rubble. Outcrops festooned with soft corals, sponges and some isolated hard corals.

132 (13) Ashmore Reef
Eugene McDermott Shoal
Outer reef slope - steep cemented reef slope with coral rubble and Halimeda distorta. Soft coral and hard coral communities were diverse, but scattered as individual colonies.

Outer reef slope - high energy fore-reef front consisting of pavement with many small to medium outcrops, with soft corals, sponges and hard corals, including branching and plate Acropora.

Outer reef slope - high energy fore reef station swept by wave action and strong currents. Reef pavement with shallow surge grooves were dominated by Sinularia and Lobophytum, and Halimeda.

Lagoon - sand, rubble, and rhodolith field with isolated coral outcrops with encrusting corals, plate Acropora, soft corals and hydroids.

Lagoon - large outcrop with sloping $\left(45^{\circ}\right)$ sides supporting a high diversity of corals and two species of giant clam. Whole site was dusted with fine coralline silt.

Outer reef slope - sloping reef front dropping to $30+\mathrm{m}$ to a sand and rubble bottom with a diverse coverage of soft and hard corals with the occasional larger outcrop rising above the slope.

Wave and current swept isolated shoal - mostly bare rock, coarse coralline sand and rubble with small to medium rocky outcrops, and some large monolithic hard coral colonies. Rocky outcrops with abundant soft corals, and branching and plate Acropora.

Wave and current swept isolated shoal - mostly bare rock covered with algal turf, coarse coralline sand and wide, but shallow, surge grooves filled with rubble and small to medium sized rocky outcrops. 
collected M. Bryce, 29 September 2013; WAM Z67023, five whole specimens, Station 133/K13, Ashmore Reef, NW Australia, $12.27478^{\circ} \mathrm{S}, 122.98128^{\circ} \mathrm{E}, \mathrm{SCUBA}$, depth $13 \mathrm{~m}$, collected M. Bryce, 30 September 2013; WAM Z67064, three whole specimens, Station 139/K13, Ashmore Reef, NW Australia, $12.24147^{\circ} \mathrm{S}, 122.99586^{\circ} \mathrm{E}$, SCUBA, depth $13 \mathrm{~m}$, collected M. Bryce, 2 October 2013; WAM Z67124, four whole specimens, Station 146/K13, Vulcan Shoals, NW Australia, 12.79930 S, $124.26672^{\circ} \mathrm{E}$, SCUBA, depth $20 \mathrm{~m}$, collected M. Bryce, 6 October 2013; WAM Z67138, one whole specimen, Station 147/K13, Eugene McDermott Shoals, NW Australia, $13.07686^{\circ} \mathrm{S}, 124.58352^{\circ} \mathrm{E}$, SCUBA, depth $20 \mathrm{~m}$, collected M. Bryce, 6 October 2013; WAM Z67184, one whole specimen, Station N55, Pilbara, NW Australia, $20.33722^{\circ} \mathrm{S}, 115.56782^{\circ} \mathrm{E}$, SLED, depth $45 \mathrm{~m}$, collected D. Thomson, 2013; WAM Z66635, one whole specimen, Station 107/K12, Echuca Shoals, NW Australia, $13.89635^{\circ} \mathrm{S}, 123.89476^{\circ} \mathrm{E}$, SCUBA, depth $22 \mathrm{~m}$, collected M. Bryce, 18 October 2012; WAM Z66642, one whole specimen, Station 109/K12, Heywood
Shoals, NW Australia, $13.43058^{\circ} \mathrm{S}, 124.01858^{\circ} \mathrm{E}$, SCUBA, depth $23 \mathrm{~m}$, collected M. Bryce, 19 October 2012; WAM Z66643, one whole specimen, Station 109/ K12, Heywood Shoals, NW Australia, $13.43058^{\circ} \mathrm{S}$, $124.01858^{\circ} \mathrm{E}$, SCUBA, depth $23 \mathrm{~m}$, collected M. Bryce, 19 October 2012; WAM Z67192, one whole specimen, Station 4, Ashmore Reef, NW Australia, 12.24369 ${ }^{\circ}$, $122.24369^{\circ} \mathrm{E}$, SCUBA, depth $15 \mathrm{~m}$, collected L.M. Marsh, 12 September 1986; WAM Z67193, five whole specimens, Station 13, Ashmore Reef, NW Australia, $12.17297^{\circ} \mathrm{S}, 123.06116^{\circ} \mathrm{E}, \mathrm{SCUBA}$, depth $12 \mathrm{~m}$, collected L.M. Marsh, 16 September 1986; WAM Z67194, one whole specimen, Station 19, Ashmore Reef, NW Australia, $12.24147^{\circ} \mathrm{S}, 122.99586^{\circ} \mathrm{E}$, SCUBA, depth 20 m, collected L.M. Marsh, 19 September 1986; WAM Z67184, one whole specimen, Station 56551, Pilbara, NW Australia, $20.33722^{\circ} \mathrm{S}, 115.56782^{\circ} \mathrm{E}$, sled, depth $45 \mathrm{~m}$, collected D. Thomson, 2013. Additional material was reported and examined in situ by M. Bryce from the following stations, but not collected: Station 108/ K12, Echuca Shoals, NW Australia, $13.90069^{\circ} \mathrm{S}$,

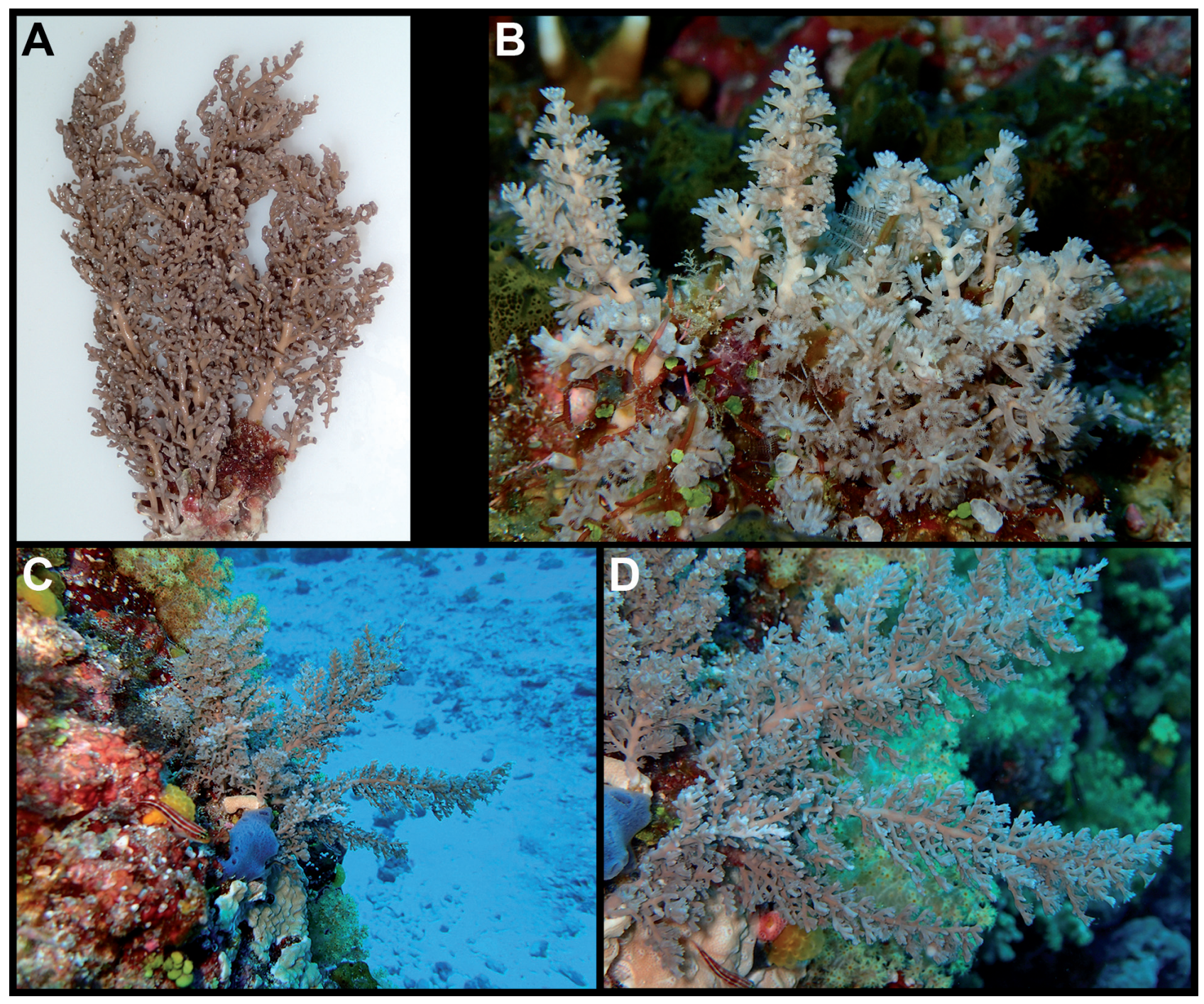

FIGURE 2 Coelogorgia palmosa WAM Z66642 (A, B) and WAM Z66643 (C, D) A. On deck; B-D. in situ. 


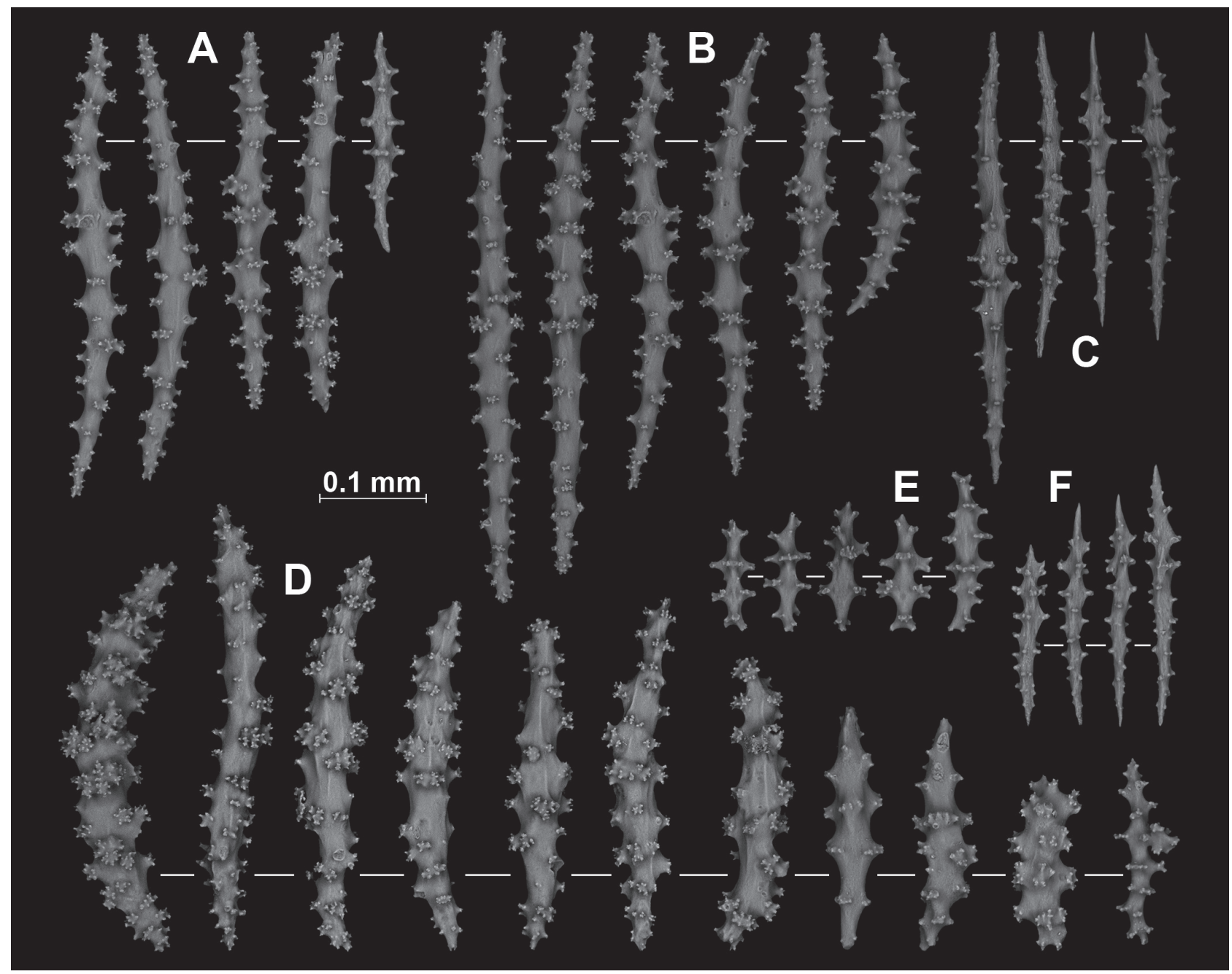

FIGURE 3 Coelogorgia palmosa WAM Z67064 sclerites. A. Surface of the branches; B. Interior of the branches; C. Surface of the stem; D. Interior of the stem; E. Polyp body; F. Tentacles.

$123.89345^{\circ} \mathrm{E}, \mathrm{SCUBA}$, depth 19m, 18 October 2012; Station 135/K13, Ashmore Reef, NW Australia, $12.24369^{\circ} \mathrm{S}, 122.24369^{\circ} \mathrm{E}$, SCUBA, depth $13 \mathrm{~m}, 1$ October 2013; Station 136/K13, Ashmore Reef, NW Australia, $12.19448^{\circ} \mathrm{S}, 123.05015^{\circ} \mathrm{E}$, SCUBA, depth 6m, 1 October 2013; Station 148/K13, Heywood Shoals, NW Australia, $12.44741^{\circ} \mathrm{S}, 124.03244^{\circ} \mathrm{E}, \mathrm{SCUBA}$, depth 23m, 7 October 2013.

\section{DESCRIPTION}

The colonies are bushy and aborescent (Figure 2A-D). They vary in size, but in general, are very similar in shape, colour, arrangement of polyps and sclerite composition. The colonies consist of a stem and branches which are arranged in alternate succession and branch off the main stem at steep angles. The branches may bear twigs. The colonies are between $36-360 \mathrm{~mm}$ tall and 11-126 mm wide, with the side branches being between 10-66 mm long and mainly between $4-9 \mathrm{~mm}$ wide. The thickness of the stem above the base varies between 2-7 $\mathrm{mm}$. All colonies are 'rigid and brittle, with only the twigs having a slight elasticity' as described by Wright and Studer 1889. The polyps are not retractile. The axial polyps are very long, the lateral polyps are short and numerous. The spicules are distributed through the entire colony, including the tentacles, and consist of straight and curved spindles with spinose warts. On the surface and in the interior of the branches the sclerites are mainly between $0.20-0.45 \mathrm{~mm}$ long (Figure 3A, B). On the surface of the stem the sclerites are between $0.15-0.30$ $\mathrm{mm}$ long and in the interior coenenchyme of the stalk between $0.30-0.40 \mathrm{~mm}$ long (Figure 3C, D). Sclerites in the polyp body measure between $0.25-0.40 \mathrm{~mm}$ in length and tentacle sclerites are between $0.20-0.26 \mathrm{~mm}$ in length (Figure 3E, F).

Colour: In situ the colonies were uniformly cream to light brown and slightly darker on deck (Figure 2). In alcohol specimens are cream to light brown. Sclerites are colourless.

Habitat: Outer and fore reef slopes, lagoons, and submerged shoals (Table 1).

Remarks: Our material fully agrees with the detailed description of C. palmosa by Wright \& Studer 1889 in growth form and all other morphological features. 


\section{Family Ifalukellidae Bayer, 1955}

\section{Genus Plumigorgia Nutting, 1910}

Plumigorgia Nutting, 1910: 32; Alderslade 1986 3(1): 117.

\section{TYPE SPECIES}

Plumigorgia hydroides Nutting, 1910 (by monotypy).

\section{DIAGNOSIS}

Colonies pinnately branched, planar to compressed or bushy with small calcified holdfasts. Axis calcified, but flexible. Polyps monomorphic, small, forming low mounds or completely retractile within the general coenenchyme and may have sclerites. Coenenchyme may be very thin or very thick. Sclerites absent to abundant, small, occurring in the shape of ovals, subspheroids, peanuts, crosses, multiradiate stars, and irregular shapes. Sclerites colourless. (Alderslade 1986, Fabricius \& Alderslade 2001).

\section{Plumigorgia hydroides Nutting, 1910}

(Figures 4-6, 7; Table 1)

Plumigorgia Nutting, 1910: 32-33, Plate IX, Figs. 3, 3a; Plate XI, Fig. 4; Alderslade 1986 3(1): 115, 117, Fig. 20.

\section{MATERIAL EXAMINED}

WAM Z67094, one whole specimen, Station 142/K13, Hibernia Reef, NW Australia, $11.98815^{\circ} \mathrm{S}, 123.33585^{\circ} \mathrm{E}$, SCUBA, depth 20 m, collected M. Bryce, October 2013.

\section{DESCRIPTION}

In situ the colony shows a bushy appearance with the branches being arranged in irregular parallel rows, i.e. planar (Figure 4). The preserved specimen is profusely branched in one plane with a main stem of approximately $6 \mathrm{~mm}$ in diameter (Figure 5). It is $285 \mathrm{~mm}$ in height and $170 \mathrm{~mm}$ wide. The calcified axis is round, but most of the branches are slightly laterally flattened due a bilateral thickening of the thin coenenchyme. The colony shows some degree of bushyness with some branches diverging 'out of plane', turning vertically and ramifying more or less parallel to the main plane (Figures 4, 5). The first major branching occurs $33 \mathrm{~mm}$ up from the place of attachment, where the main stem divides into two branches. Further branching occurs above this point into numerous smaller branches. The branches are between 35-60 mm long. From the latter terminal twigs arise in an alternating pinnate mode. They are between 6-14 mm long, and slightly expanded at their base of attachment. The fine hair-like nature of the axis of the terminal twigs is quite evident, making the colony resemble a 'plumularian hydroid' as described by Nutting 1910. The polyps are numerous on the terminal twigs with approximately 0.1 $\mathrm{mm}$ between centers. They are arranged biserially, often opposite, but also sub-opposite or alternate (Figure 4B). They are totally retractile into the general coenenchyme. The apical end of the twigs is often devoid of polyps. On the branches polyps are also arranged biserially, but are fewer and more irregularly distributed, becoming scarce in older parts of the colony.

The small sclerites are densely aggregated over the whole colony, with the exception of the shiny goldenbrown coenenchyme of the stem and main branches. Under the microscope the sclerites of the twigs appear as a densely aggregated white layer. They are derived from basic rod shapes with the majority of sclerites being somewhat rectangular and fewer being circular-oval (Figure 6). Often the oval is constricted in the middle producing a peanut-shape. The majority of sclerites are between $0.03-0.05 \mathrm{~mm}$ long and $0.01-0.03 \mathrm{~mm}$ wide, with the surface covered by fine granules. There was no distinct difference in sclerite shape or size between the upper or lower terminal twigs in the colony, nor between

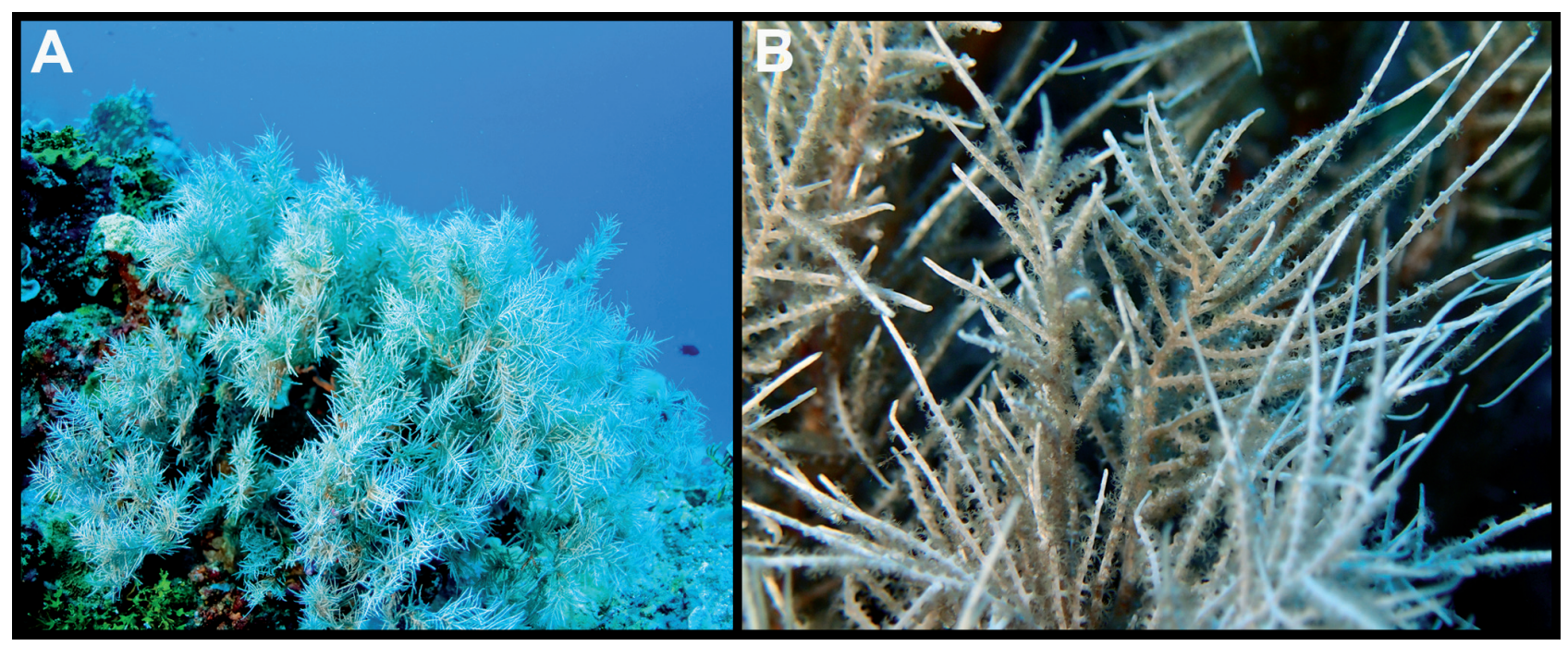


the apical ends of the twigs or the parts attached to the stem.

Colour: In situ and on deck the colony was yellowishwhite with a golden-brown stem (Figures 4, 5). The preserved specimen has the same colour. Sclerites are colourless.

Habitat: Fore reef slope (Table 1).

Remarks: Our material agrees with the description and detailed analysis of $P$. hydroides by Alderslade (1986). That author also discusses the usage of overall growth form for identification and the possibility of ecotypic variations in colony shape. It is possible that for many species planar and non-planar forms exist. Unfortunately descriptions are often based on preserved colony fragments with little documentation of how the colonies grow in situ. Also, specimen shape and appearance can change during storage and handling causing degradation of the sample.

\section{MOLECULAR ANALYSES}

In octocorals the mitochondrial locus mtMutS, has been extensively used for the molecular analysis and provides the most complete taxonomic coverage available for the subclass (e.g. McFadden et al. 2006). However, for this contribution the main goal was not to reconstruct the molecular phylogeny, but rather to corroborate the morphological results. mtMutS sequences obtained for Coelogorgia (WAM Z67064)

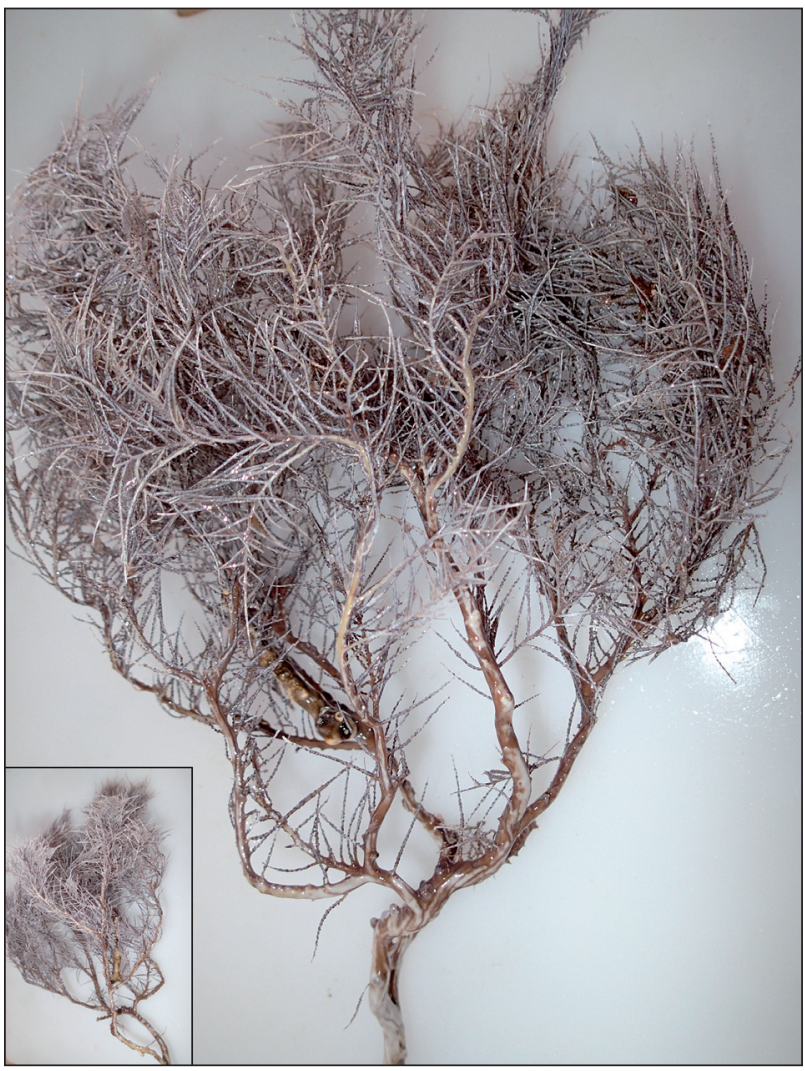

FIGURE 5 Plumigorgia hydroides WAM Z67094 photographed on deck.

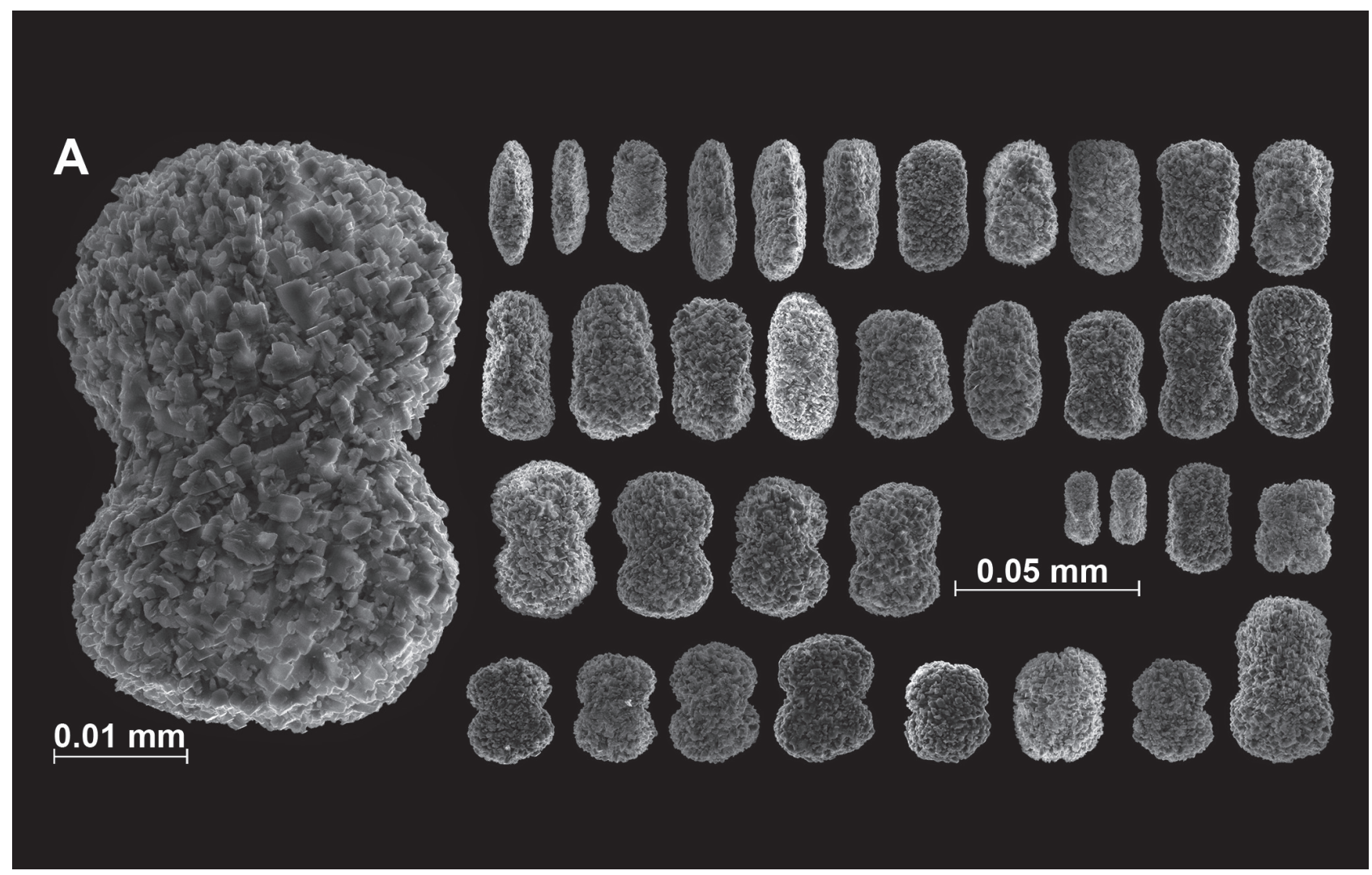

FIGURE 6 Plumigorgia hydroides WAM Z67094 sclerites. A. detail of surface; B. range of shapes. 


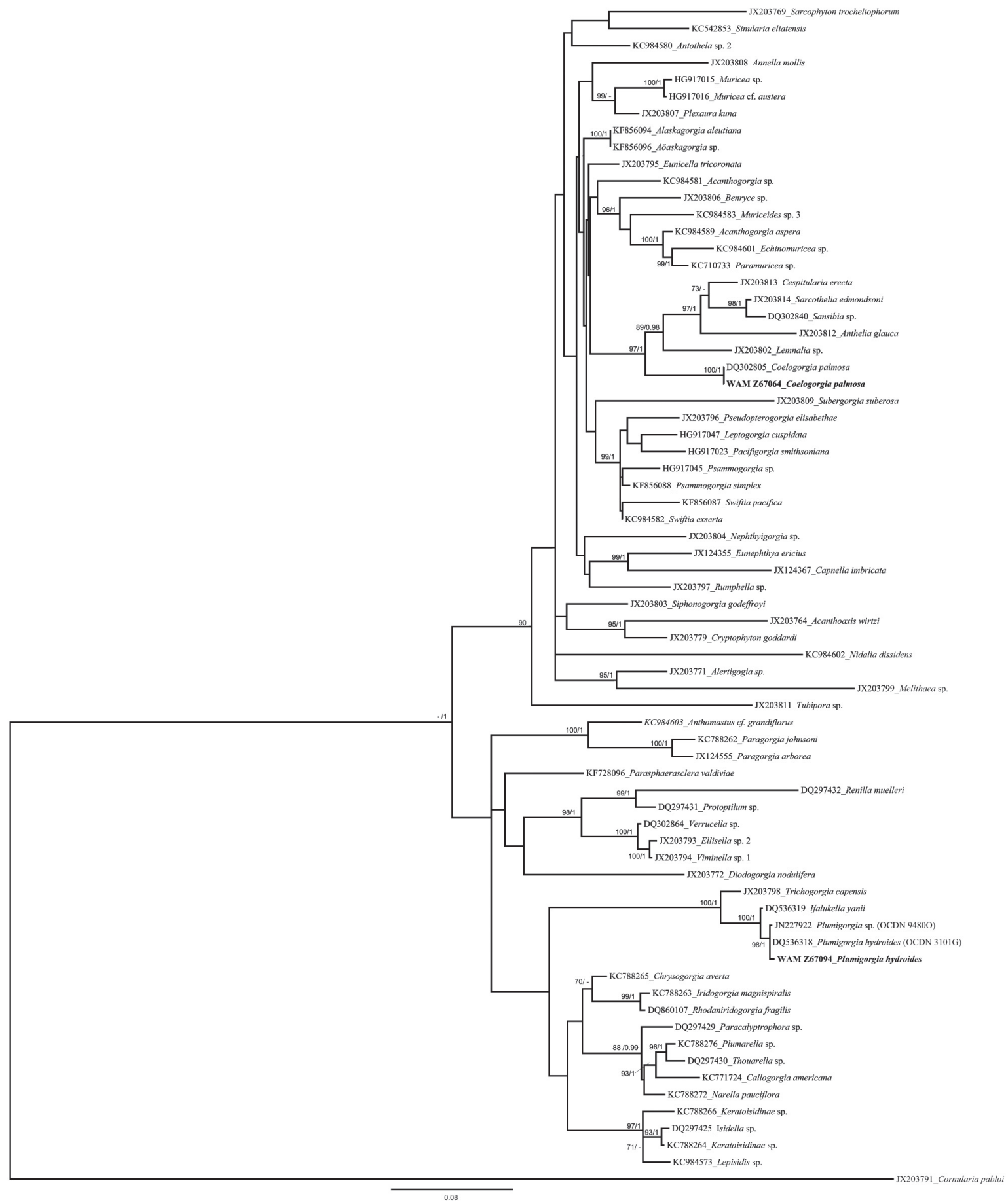

FIGURE 7 Maximum likelihood tree of mtMutS. Values at the nodes refer to bootstrap (left) and posterior probability (right). Alphanumeric codes before species name represent GenBank accession numbers, in brackets are museum vouchers. Cornularia pabloi was used as the outgroup.

and Plumigorgia (WAM Z67094) match respectively $100 \%$ with the Coelogorgia palmosa (DQ302805) and $99 \%$ with the two Plumigorgia (P. hydroides and $P$. sp.) (DQ536318, JN227922) sequences downloaded from GenBank. The two phylogenetic methods supported the same tree topology (Figure
7). Specimens belonging to Plumigorgia grouped together with two Ifalukellidae species (Ifalukella yanii and Trichogorgia capensis), well supported by both bootstrap and posterior probability values. The Stolonifera group is considered to be polyphyletic (McFadden and Ofwegen 2012). 


\section{SUMMARY}

Here we report on two new Australian geographical records of the bushy octocorals Plumigorgia hydroides and Coelogorgia palmosa from outer reefs and mid shelf shoals off the Kimberley coast, Western Australia. Biological surveys were undertaken at 24 Ashmore and Hibernia Reef stations, and at six stations at isolated submerged shoals in the mid shelf region.

The genus Plumigorgia has been reported from the Great Barrier Reef, the Chesterfield and Marshall Islands and Micronesia in the Pacific, from Indonesia in the Indian Ocean, and also from the China Sea (Alderslade 1986, Fabricius \& Alderslade 2001, Grasshoff \& Bargibant 2001). This is the first record for this genus in Western Australia. From five species described within this genus three are described from Australian waters, P. astroplethes Alderslade, 1986, P. schuboti Alderslade, 1986, and P. terminosclera Alderslade, 1986, but were only recorded from the Great Barrier Reef off the east coast of the continent. The other two described species are P. wellis Bayer, 1955, collected from the central West Pacific, and $P$. hydroides Nutting, 1910 formerly only collected from central Indonesia. This is the first time $P$. hydroides has been collected in Australia. Occurrence was extremely low with the species found only at one site at Hibernia Reef occupying about $1 \mathrm{~m}^{2}$ in area.

In contrast, the second new Australian record, the monotypic Coelogorgia palmosa, had a surprisingly wide distribution and high abundance at some stations (Table 1). It has been formerly reported from the West Indian Ocean from South Africa (Williams 1992), Mozambique (Wright \& Studer 1899, Tixier-Durivault 1966, 1972), the islands of Zanzibar, Madagascar (Tixier-Durivault 1966, 1972, Verseveldt 1971) and the Seychelles (Milne-Edwards \& Haime 1857). In the Pacific Ocean it has been collected from Indonesia (Thomson \& Dean 1931) and Palau (McFadden et al. 2006).

In Australia, Coelogorgia sp. was mentioned for the first time by Marsh (1993) from Ashmore Reef. The specimens were collected in 1986 at three sites and stored at WAM. The significance of this discovery had been overlooked and the specimens are now identified in this work as C. palmosa. Department of Environment and Heritage (Kospartov et al. 2006) reported $C$. sp. from a single station at Ashmore Reef, but no specimens were collected. During the WAM survey, C. palmosa was collected from six Ashmore Reef sites and four mid shelf shoal sites, while it was absent from the other 18 Ashmore and Hibernia Reef stations. While the abundance at some Ashmore Reef stations was remarkably high, with up to 100 colonies counted per dive, abundance at sampled mid shelf shoals was low (Table 1).

This survey was part of a WAM led project funded by Woodside Energy, and since 2009148 stations have been completed from inshore to outer shelf sites. Additional data from various Australian museum historical collections and both published and unpublished survey datasets were also considered. These included datasets from Western Australian locations at Ningaloo Reef, the Pilbara coastal regions and the Rowley Shoals, and from Great Barrier Reef sites along Australia's east coast. (Marsh 1986, Griffith 1997, Fabricius 2008, Keesing et al. 2011, ABRS 2011, Bryce unpublished - Pilbara and King George surveys 2013 and 2014). Searching this data revealed no occurrence of $P$. hydroides or $C$. palmosa from the Great Barrier Reef, which was further confirmed by other researchers who had undertaken octocoral surveys from the region (Katharina Fabricius, unpublished; Phil Alderslade, unpublished). However, in 2013 one new specimen of C. palmosa was dredged from $45 \mathrm{~m}$ near the Montebello Islands off Western Australia's Pilbara coast by the Commonwealth Scientific and Industrial Research Organisation (CSIRO), suggesting a wider distribution for this species along this coast, mostly unsurveyed for octocorals.

This highlights the importance of comprehensive surveys in remote areas in providing a clearer understanding of octocoral taxonomy, systematics and distribution patterns in tropical marine environments. Growing Octocorallia collections will reveal essential biogeographic data from this poorly studied area of the Western Indian Ocean (Bayer 1981), with implications for marine area protection (Fabricius 2008, Keesing et al. 2011, Richards et al. 2013).

\section{ACKNOWLEDEGMENTS}

Sincere thanks to various agencies that supported the fieldwork, including the Western Australian Museum, Woodside Energy, the National Taxonomic Research Grant (QM Museum; ABRS 209-05), and the Deutsche Akademische Austauschdienst (DAAD). Thanks also to Sergio Vargas and Gert Wörheide (LMU Munich) for providing access to the laboratory facilities, and Phil Alderslade (CSIRO) and Leen van Ofwegen (Naturalis Biodiversity Centre) for their invaluable comments on this manuscript.

\section{REFERENCES}

ABRS (2011). Australian Faunal Directory. Australian Biological Resources Study: Canberra, Australia; online at http://www.environment.gov.au/biodiversity/abrs/onlineresources/fauna/afd/index.html. Accessed 2008-2011.

Alderslade, P. (1986). New species of the gorgonian genus Plumigorgia (Coelenterata: Octocorallia) with a review of the family Ifalukellidae. The Beagle, Occasional Papers of the Northern Territory Museum of Arts and Sciences 3 : 95-122.

Bayer, F.M. (1955). Contributions to the Nomenclature, Systematics, and Morphology of the Octocorallia. Proceedings of the United States National Museum 105: 207-220.

Bayer, F.M. (1956). Octocorallia. In: R.C Moore (ed), Treatise on Invertebrate Palaeontology. Part F. Coelenterata: 
166-231. Geological Society of America and University of Kansas Press: Lawrence.

Bayer, F.M. (1981). Status of knowledge of octocorals of world seas. Seminarios de Biologia Marinha. Academia Brasiliera de Ciencias, Rio de Janiero: 3-11.

Bryce, M. and Sampey, A. (2014). Kimberley marine biota. Historical data: soft corals and sea fans (Octocorallia). Records of the Western Australian Museum, Supplement 84: pp. 101-110.

Fabricius, K. and Alderslade, P. (2001) Soft corals and sea fans - a comprehensive guide to the tropical shallow water genera of the central-west Pacific, the Indian Ocean and the Red Sea. Australian Institute of Marine Science, Townsville, $264 \mathrm{pp}$.

Fabricius, K. (2008) A brief photo guide to the shallow-water octocorals of the Rowley Shoals, Western Australia. Report to the department of Environment and Conservation, Government of Western Australia: 1-39.

Fabricius, K.E. and De'ath, G. (2001). Biodiversity on the Great Barrier Reef: large-scale patterns and turbidityrelated local loss of soft coral taxa. In: Wolanski, E. (eds.), Oceanographic Processes of Coral Reefs: Physical and Biological Links in the Great Barrier Reef: 127-144. CRC Press, London.

France, S.C. and Hoover L.L. (2002). DNA sequences of the mitochondrial COI gene have low levels of divergence among deep-sea octocorals (Cnidaria. Anthozoa). Hydrobiologia 471: 149-155.

Grasshoff, M. and Bargibant, G. (2001). Les gorgones des recifs coralliens de Nouvelle-Caledonie: 1-335. IRD, New Caledonia.

Griffith, J. (1997). The corals collected during September/ October 1997 at Ashmore reef, Timor Sea. Unpublished report to Parks Australia.

Keesing, J.K., Irvine, T.R., Alderslade, P., Clapin, G., Fromont, J., Hosie, A., Huisman, J., Phillips, J., Naughton, K.M., Marsh, L.M., Slack-Smith, S., Thomson, D. and Watson, J. (2011). Marine benthic flora and fauna of Gourdon Bay and the Dampier Peninsula in the Kimberley region of northwestern Australia. Journal of the Royal Society of Western Australia 94: 285-301.

Kospartov, M., Beger, M., Ceccarelli, D. and Richards, Z. (2006). An assessment of the distribution and abundance of sea cucumbers, trochus, giant clams, coral, fish and invasive marine species at Ashmore reef national nature reserve and Cartier Island marine reserve. UniQuest Pty Limited (Produced for the Department of the Environment and Heritage): 1-240.

Marsh, L.M. (1986). Part III: Cnidaria, other than reef-building corals. In: Berry, P.F. (ed.), Faunal Surveys of the Rowley Shoals and Seringapatam Reef, North-western Australia. Records of the Western Australian Museum 25: 37-38.

Marsh, LM. (1993). Cnidaria, other than reef-building corals, of Ashmore Reef and Cartier Island. In: Berry, P.F. (ed.) Marine Faunal Survey of Ashmore Reef and Cartier Island, North-western Australia. Records of the Western Australian Museum 44: pp. 1-91.

McFadden, C.S., France, S.C., Sanchez, J.A. and Alderslade P. (2006). A molecular phylogenetic analysis of the Octocorallia (Cnidaria: Anthozoa) based on mitochondrial protein-coding sequences. Molecular Phylogenetics and Evolution 41: 513-527.

McFadden, C.S. and Ofwegen LP van (2012). Stoloniferous octocorals (Anthozoa, Octocorallia) from South Africa, with description of a new family of Alcyonacea, a new genus of Clavulariidae, and a new species Cornularia (Cornulariidae). Invertebrate Systematics 26: 331-356.

Milne-Edwards, H. and Haime, J. (1857). Histoire naturelle des Coralliaires ou Polypes proprement dits. Paris, T.I: 324 pp.

Nutting, C.C. (1910). The Gorgonacea of the Siboga Expedition IV. The Plexauridae. Siboga-Expedite 13(B): 1-20.

Richards, Z.T, Bryce, M. and Bryce, C. (2013). New records of atypical coral reef habitat in the Kimberley, Australia. Journal of Marine Biology 363894: 1-8.

Sánchez, J.A., McFadden, C.S., France, S.C., Lasker H.R. (2003). Molecular phylogenetic analyses of shallow-water Caribbean octocorals. Marine Biology 142: 975-987.

Tixier-Durivault, A. (1966) Octocoralliaires de Madagascar et des Iles avoisinantes. Fauna de Madagascar 21: 1-456.

Tixier-Durivault, A. (1972). Nouvel apport d'Octocoralliaires de Madagascar et des Iles avoisinantes. Tethys. Supplement No. 3: 11-68.

Thomson, J.A. \& Henderson, W.D. (1906). An account of the Alcyonarians collected by the Royal Indian Marine survey ship Investigator in the Indian Ocean. Printed by order of the trustees of the Indian Museum: $128 \mathrm{pp}$.

Thomson, J.A. \& Dean, L.M.I. (1931). Alcyonacea of the Siboga Expedition with an addendum to the Gorgonacea. SibogaExpedition Reports 13(D): 1-227.

Verseveldt, J. (1971) Octocorallia from North-Western Madagascar (Part II). Zoologische Verhandelingen 117: 3-73.

Williams, C.G. (1992). The Alcyonacea of southern Africa. Stoloniferous octocorals and soft corals (Coelenterata, Anthozoa). Annals of the South African Museum 100: 249-358.

Wilson, B. (2013). The biogeography of the Australian North West Shelf: Environmental change and life's response. Elsevier, $413 \mathrm{pp}$.

Wright, E.P. and Studer, T. (1889). Report on the Alcyonaria collected by H.M.S. Challenger during years 1873-1876. Scientific Report of the Voyage H.M.S. Challenger 31: 341 pp.

MANUSCRIPT RECEIVED 27 JUNE 2014; ACCEPTED 22 OCTOBER 2014. 